
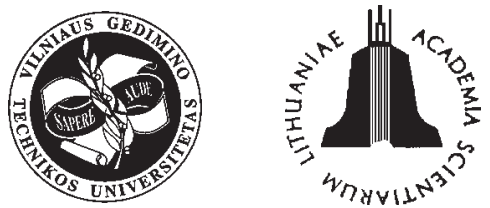

JOURNAL OF CIVIL ENGINEERING AND MANAGEMENT

http:/www.jcem.vgtu.lt

2005, Vol XI, No 3, 175-183

\title{
VERTICAL CYLINDRICAL TANK WITH ANGULAR GEOMETRICAL IMPERFECTION
}

\section{Yevgeny Gorochov, Vladimir Muschanov, Alexander Kulik, Alexander Tsyplukhin}

The Donbass State Academy of Civil Engineering and Architecture, Derzhavina St 2, 86123 Makeevka, the Donetsk Region, Ukraine.E-mail:mvf@dgasa.dn.ua

Received 28 Jan 2005; accepted 18 May 2005

\begin{abstract}
In this paper the results of experimental research are given for the stress and strain state of a near seam zone. The research is executed on large-scale model of a zone of vertical cylindrical tank assembly connection with a geometrical imperfection. As a result, the dependence is received between values of the basic stress, which take place in a tank wall of the ideal form, and local stress, which arise in a seam zone. It is proved by experiments that when the ring stress achieves value $100 \mathrm{mPa}$, then the local stress in a near seam zone achieves the stress of $280-300 \mathrm{mPa}$. Hence, they exceed three times their major importance. These stress values are coordinated satisfactorily to the data, which are received by a theoretical way.
\end{abstract}

Keywords: vertical cylindrical tank, stress and strain state, vertical welding joint, geometrical imperfection, sag.

\section{Introduction}

Rolling-on method is often used to construct tanks in Ukraine and some other countries of CIS at present. But this method has certain disadvantages alongside with many advantages $[1,2]$. One of them is vertical joints mechanical closing, which causes weld affected zone damage in transit and mounting and field joint defects in the form of angularity). This shortage is the most conspicuous when mounting and running large-volume tanks (20000 $\mathrm{m}^{3}$ and larger). This feature is indicated as very relevant in [3] too. Permanent usage of the product can cause cracking in weld affected zone (Fig 1).

Large tanks failure analysis shows that cracks in joints zone result in about $10 \%$ of fatigue failures [4, 5]. Besides, the geometrical imperfections of significant size may cause buckling of a wall of shell $[6,7]$. Such destructions result in financial losses, do harm to the environment and can lead to human victims. In the home specification of tanks there are no instructions as to normalise the operation ratio of a tank vertical field weld under unfavourable conditions of an alternating lowcycling loading [8].

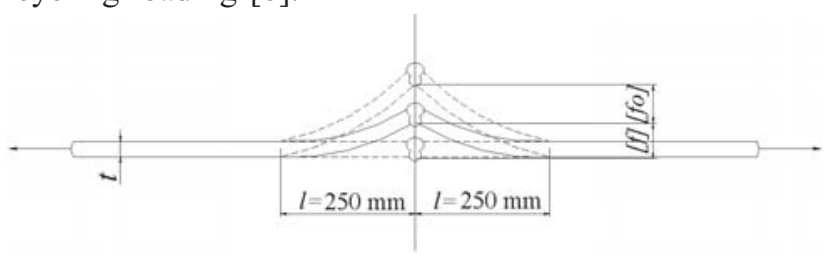

Fig 1. Change of a joint position when filling and emptying a tank
Scientists from CIS suggest a few means of taking some special means for working with imperfect weld into account.

Institute CNIIPSK named after Melnikov has proposed an analytical design procedure of vertical cylindrical tanks fatigue durability [8], [9] but the use of the given procedure is aimed only at tank operation stage on the basis of research.

An approach proposed by Koloskov A. D. provides a field joint reliability allowing for stresses to increase in VCT vertical field joint zone caused by joint angularity and edges displacement (warping) taking into account elastic and plastic adaptation of weld affected zone [10], [11].

Calculations of additional stresses are given in [10], [12]: article [10] (equation 1a) setting out the calculations of a vertical field weld zone at an elastic stage, and article [12] (equation 1b) covering the same calculation with regard to an elastic-plastic adapting of an aroundweld zone.

$$
\begin{gathered}
\sigma=\sigma_{0}\left(1 \pm 6 \frac{\mathrm{f}}{t}\right) \\
\varepsilon_{M A X}=B \frac{I_{0}}{I}\left(1-\varphi^{2}\right) \frac{\sigma_{y}}{E},
\end{gathered}
$$

where $\sigma_{0}=\frac{q r}{t}$ is the basic stress in a wall of an ideal form, $f-$ an arrow of sinking a tank field weld. 


$$
\varphi=\frac{N}{\sigma_{\mathrm{y}} t} \quad(0<\varphi<1)
$$

$\xi=\frac{3-B}{2}-$ a relative height of an elastic core of a cross section $(0<\xi<1)$; $\mathrm{B}=1,6(\xi=0,7)$.

As a result of using this approach, the value of a stress growth decreases several times. But as the carried out investigations have shown, $\mathrm{t}, \sigma_{\mathrm{y}}-\mathrm{a}$ steel thickness and yield strength, $f$ - arrow of sinking (Fig 1) have a very large spread, on the one hand, and, on the other hand, even their insignificant change greatly influenced the stressed-strained state (SSS) (an extra value tax). An analysis of initial data has shown that even the suggested formula does not take into account all structural peculiarities of a wall in a vertical weld zone; thus, the data obtained represent a very approximate estimate of tank cyclic durability. Besides, this technique is based on using Prandtle idealised diagram and a simplified technique for detecting a given moment of inertia of an elasticplastic strip under a double-sided yield in a joint zone. More-over, in some cases it shows a great overstating of values of stresses in an aroundwell zone. Similar analytical approaches are used when calculating of a wall of the tank taking account of the influence of local geometrical imperfections $[13,14]$ too, caused by welding stresses including [15].

Institute named after Ye Paton. carried out VCT repaired joints SSS numerical research and specimenstrips laboratory tests. The experimental data obtained have allowed to find dependence between the sag and the number of loading which the specimen had carried before failure, and also the dependence of fatigue strength on steel quality and thickness [12]. Having studied and tested strip samples with different values of an arrow of sinking on the base of changing in $500 \mathrm{~mm}$ (Table 1).

There is no tolerance for VCT joints angular deformation in Ukrainian $[16,17]$ and foreign normative documents. That's why it is difficult enough to conduct field joints proximate control, using the existing methods, under VCT technical attestation and certificate. An improved procedure taking into account the basic postulates [10] and recommendation [9] and [12] has been

Table 1. Dependence of a number of loading cycles until a crack appears

\begin{tabular}{|c|c|c|c|c|c|}
\hline \multirow{2}{*}{$\begin{array}{l}\text { Steel } \\
\text { quality }\end{array}$} & \multirow{2}{*}{ 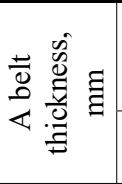 } & \multicolumn{4}{|c|}{$\begin{array}{l}\text { A number of loading cycles until a } \\
\text { visually observed crack appeared } \\
\text { (with a probability of } 5 \% \text { ) }\end{array}$} \\
\hline & & $\begin{array}{l}5 \mathrm{x} \\
10^{3}\end{array}$ & $\begin{array}{c}7,5 \mathrm{x} \\
10^{3}\end{array}$ & $10^{4}$ & $\begin{array}{c}1,25 \mathrm{x} \\
10^{4}\end{array}$ \\
\hline Ст3сп5 & 12 & 12 & 10 & 10 & 9 \\
\hline $09 \Gamma 2 \mathrm{C}$ & $12-16$ & 10 & 7 & 5 & 3 \\
\hline $16 Г 2 A \Phi$ & 17 & 4 & 3 & 2 & 2 \\
\hline
\end{tabular}

On the basis of the experimental data they have recommended to set a limit for an arrow of sinking on the value at which a low-cyclic fatigue strength could be acceptable. developed in DSACEA. It should be noticed that not a single technique mentioned above did not aim at considering the SSS peculiarities of a VCT field weld with a help of an operation ratio $\gamma_{C}$, which is needed when using the method of limiting states.

The purpose of this work was to investigate the effect of geometrical angular imperfections on SSS character in VCT field joints by making the tank joint research to test theoretical premises of developed procedure and to eliminate scale factor effect.

On the basis of the achieved results it is necessary to assign finalised values of limiting sag for VCT joints.

\section{The suggested analytical techniques of calculation at the elastic-plastic stage}

\section{a) a determinate interpretation of the technique}

The technique developed in the DonNACE\&A is based on the above-listed techniques but it takes into account the above-mentioned demerits. The design scheme of a mount joint for analytical calculation in the determinate interpretation is shown in a Fig 2.

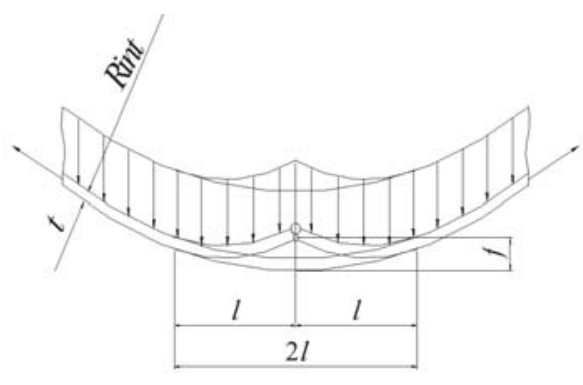

Fig 2. Scheme of calculating tank wall with an imperfection in the form of angularity

Among the merits of this technique we should mention that a simplified diagram of Prandtle is not used here because it does not meet the requirements of an accurate calculation as it presupposes that a material runs only up to a yield strength meaning, and then stresses stop growing because of deformations. But if, without additional reserve, it could be accepted for low-carbon steels having a length of a yield site 2,5\%, for lowalloyed steels this prerequisite is not right as their yield site is not large (up to $1 \%$ ), and then a steel passes into a zone of self-strengthening. But these are low-alloyed steels used in large-volume tanks and for them this problem is especially urgent. Instead of the diagram of Prandtle the real diagram of steel tension is used; the diagram was obtained when steel was tested for rupture, every steel quality being tested individually.

To find an elastic-plastic moment of a strip, a more accurate technique suggested in [18] was used too:

$$
I=I_{0}\left\{\beta+\frac{3}{2}(1-\beta) \xi\left[1-\left(\frac{\varphi \xi}{\xi+\beta(1-\xi)}\right)^{2}-\frac{\xi^{2}}{3}\right]\right\}
$$


Within the developed approach the following statements are recommended for using:

- a stress in a joint

$$
\sigma_{\max }=\beta \frac{I_{0}}{I}\left(1-\varphi^{2}\right)(3-2 \xi) \sigma_{\mathrm{y}}
$$

having made some replacement to make the solution easier,

$$
\begin{gathered}
K=\left(\frac{\varphi \xi}{\xi+\beta(1-\xi)}\right) ; \quad S=\frac{I}{I_{0}} . \quad \beta=\frac{E_{\Phi}}{E} ; \\
L=\left(1-\varphi^{2}\right)(3-2 \xi) \sigma_{\mathrm{y}},
\end{gathered}
$$

we finally obtain the equation in the determinated form

$$
\sigma=\beta \frac{L}{S}
$$

Comparison of the results obtained with the technique developed in the DonNACEA is shown in Fig 3. It can be seen there is technique in [12] gives an overstated results as compared to the technique developed.

\section{b) a probabilistic interpretation of the technique}

A probabilistic calculation means the usage of formula (4) expanded by Taylor series, as it is recommended in classical work [19], for example.

After expanding and making some manipulations and replacements we shall finally obtain a formula to calculate stresses in a field weld taking into account random parameters of a steel thickness and yield strength:

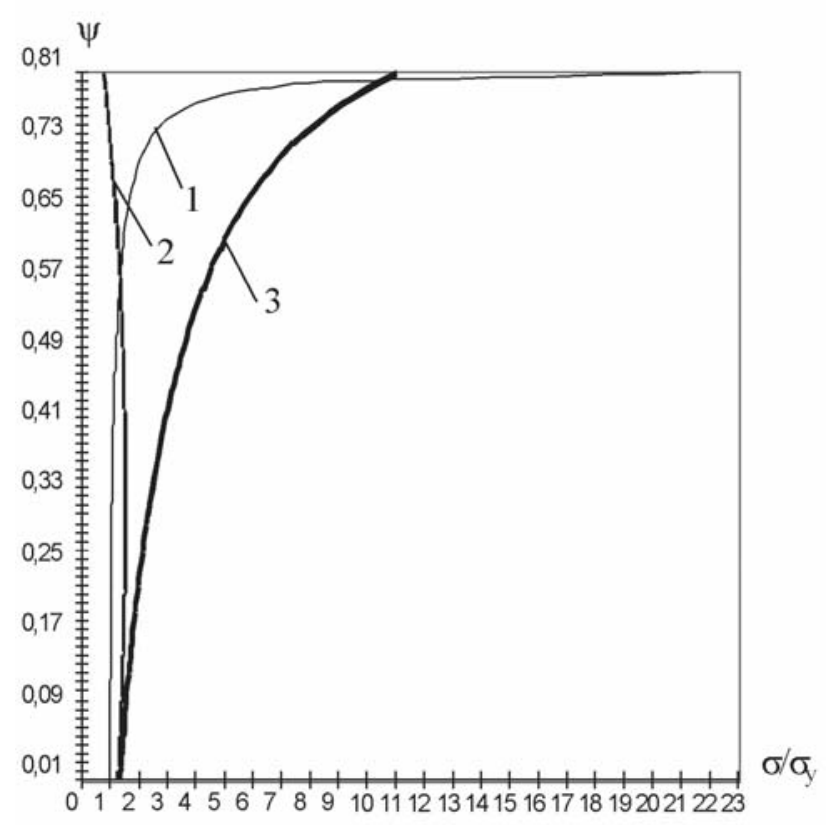

Fig 3. A diagram of comparing results obtained by the developed technique and the one suggested in [12]: $1-\mathrm{a}$ technique based on use of the equation 1á, 2 - a technique based on the equation 1í, 3 - a technique based on the equation 3

$$
\sigma=\mathrm{E}\left\{\frac{\mathrm{L}}{\mathrm{S}}+\mathrm{V}^{2} \frac{\mathrm{L}(1-2 \mathrm{H})+\mathrm{J}}{\mathrm{S}}+\frac{\mathrm{V}^{4}}{2}[\mathrm{~L}(1+4 \mathrm{H}(\mathrm{H}-1))-2 \mathrm{H}(\mathrm{J}+\mathrm{L})]\right\},
$$

where $\mathrm{V}$ is a coefficient of variation;

$$
\mathrm{H}=\frac{3 \mathrm{~K}^{2}(1-\beta) \xi}{\mathrm{S}} ; \quad \mathrm{J}=(3-2 \xi) \varphi^{2} \bar{\sigma}_{y} .
$$

\section{c) the technique of determining operation ratio}

To come over from stresses to the operation ration let's use formula (5)

$$
\psi\left(\gamma_{\mathrm{c}} \leq \tilde{\mathrm{G}}=\frac{\widetilde{\sigma}_{\mathrm{y}}}{\widetilde{\sigma}}\right),
$$

where $\psi-$ a required level of providing inequality; $\tilde{\sigma}_{\mathrm{y}}-$ a random meaning of a steel yield strength; $\tilde{\sigma}-$ a stress in a joint zone which is calculated regarding a random character of $\tilde{t}, \tilde{f}$.

Thus, having investigated a number of tanks, we obtained data to study values of a steel yield strength, thickness and an arrow of sinking a field weld.

The technique suggested implies a probabilistic base of an operation ratio, and is based on equation (5), whose parameters have resulted from statistic investigations.

Results of calculations by formulas $(6,7)$. Let us plot an operation ratio $\gamma_{c}$ as a function of a parameter $\varphi$, changing within $0<\varphi<0,7$, shown in Fig 4 .

\section{An experimental research of the joint SSS using large-scale model}

Joint SSS experimental research using large-scale model has also been conducted, it has proved correctness of the results obtained on the basis of developed procedure. Some results of statistical studies of yield

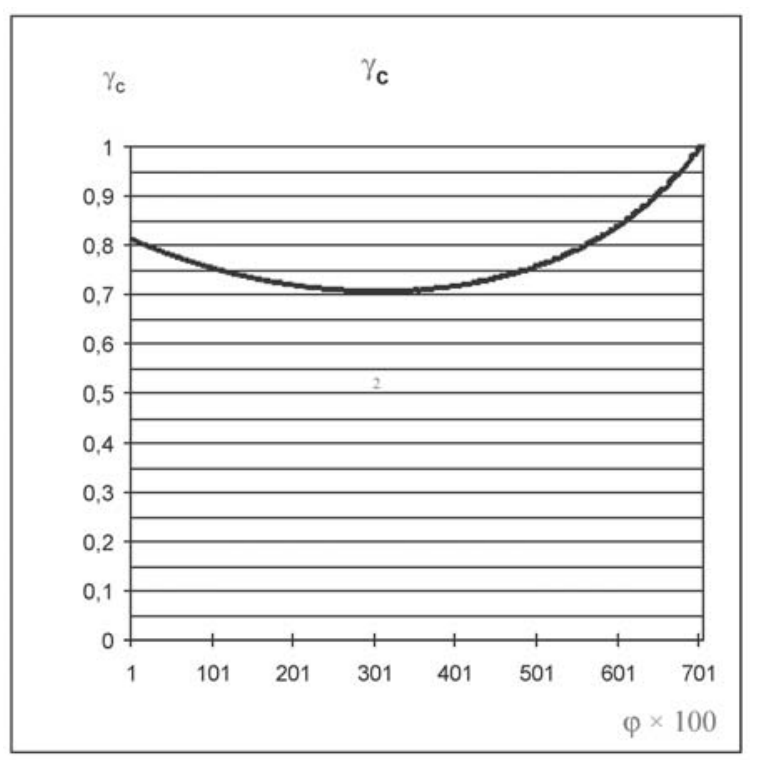

Fig 4. A plot of an operation ratio $\gamma_{c}$ as function of a parameter $\varphi$ 


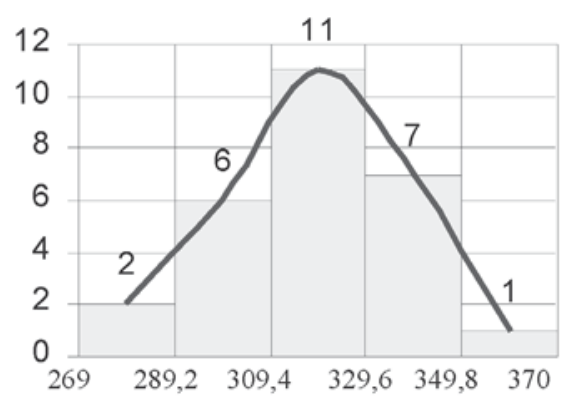

Fig 5. Plot of a value of yield strength $\sigma_{\mathrm{y}}(\mathrm{MPa})$ of steel $09 \Gamma 2 \mathrm{C}(\mathrm{t}=11 \ldots 13 \mathrm{~mm})$

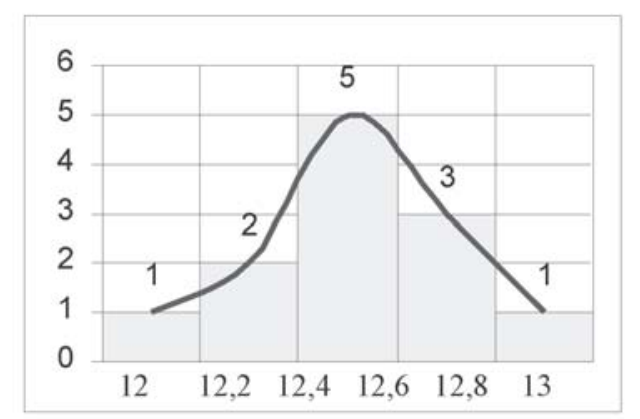

Fig 6. Plot of thickness distribution of steel $09 \Gamma 2 \mathrm{C}$ $(\mathrm{t}=13 \mathrm{~mm})$

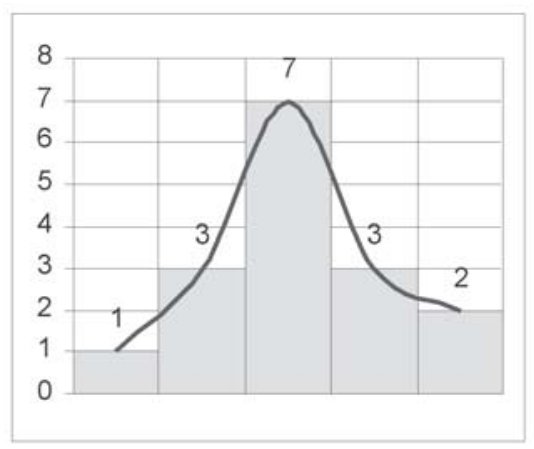

Fig 7. Plot of value distribution of a sinking field weld $f$ (mm) VCT-30000

strength, thickness, sinking field weld of tank steel 09Г2C are shown in a Figs 5, 6, 7.

To conform analytical prerequisites of the technique there has been developed and made a scale model of a vertical field weld. The model is an air-tight reservoir, the larger sides of which - two welded shells - being the membranes of a sheet steel of 4 and $5 \mathrm{~mm}$ thickness forge-rolled in radius of $2 \mathrm{~m}$. One of the sides of each shell was bent in radius of $0,05 \mathrm{~m}$ to create angularity. Then these shells were welded together by two.

An arrow of sinking on the side of steel of $4 \mathrm{~mm}$ in thickness was $18 \mathrm{~mm}$, and on the side of steel of $5 \mathrm{~mm}$ in thickness it was $25 \mathrm{~mm}$ (Fig 8).

A testing zone has been estimated by calculations beforehand, this zone having an upper and bottom bounds at a range of $0,5 \mathrm{~m}$ from model cover and bottom; a full height of the zone is $1 \mathrm{~m}$, its width $1 \mathrm{~m}$ too. To have an SSS of the joint model estimated in an aroundweld zone

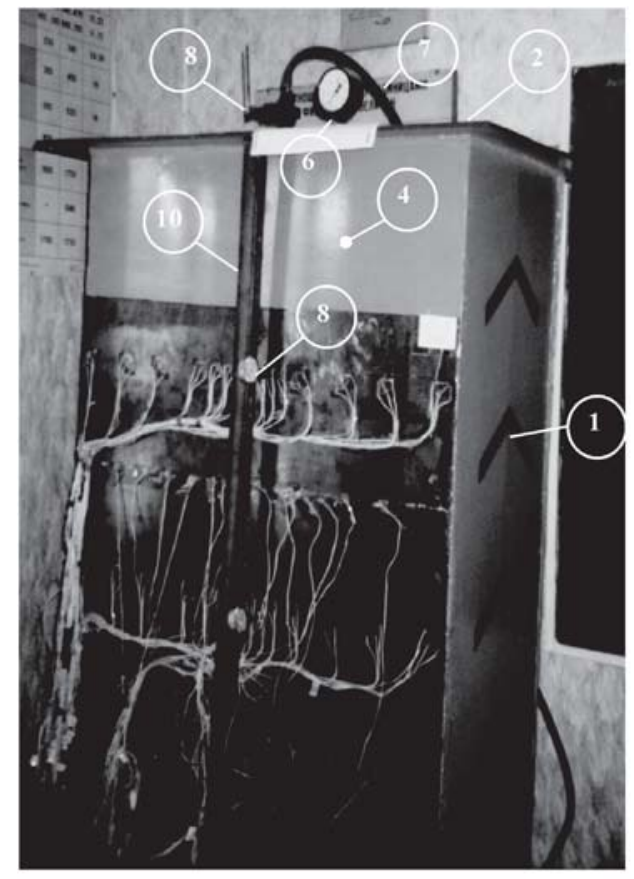

Fig 8. Model during tests

beforehand, there was applied an improved design procedure based on the technique [10] but considering changes given in [18]. Membrane deformations in a longitudinal and cross-sectional direction were fixed by strain gauges, a joint deflection under loading by clock-like indicators fastened on an arm in the form of an angle. In the zone of elastic-plastic deformations (within a joint zone) there were bounded shortbased strain gauges (the base of $5 \mathrm{~mm}$ ). The rest of shell area in an elastic stage was bonded with strain gauges of the $20 \mathrm{~mm}$ base. At pressure $20 \mathrm{kPa}$ the level of the main membrane stresses was $100 \mathrm{mPa}$. The model scheme with accommodation of instruments is shown in a Fig 9.

Having analysed the reading of strain gauges, we obtained points shown in Fig 10 and which are then approximated by the curve of the fourth power. Horizontal displacements of joint at various sizes of internal pressure shown in Fig 11.

When testing the model, let us experimentally find a value of stresses in an aroundweld zone. A comparison between experimental and theoretical studies has shown that a gap between them does not exceed 15-20\%.

\section{An experimental research of the VCT joint}

Experimental research was carried out on tank No 2 volume $5000 \mathrm{~m}^{3}$ of Zuyevskaya TPS fuel oil handing system (Fig 12). The joint zone was being tested in elastic state by tank loading with hydrostatic load (fuel oil was poured up to the height of $2,8 \mathrm{~m}$ ).

The density of the product poured in is $0,98 \mathrm{t} / \mathrm{m}^{3}$, the temperature is $89^{\circ} \mathrm{C}$ (according to the information of Zuyevskaya TPS operation service). The field joint sag is $12 \mathrm{~mm}$ in the central part of zone II. 

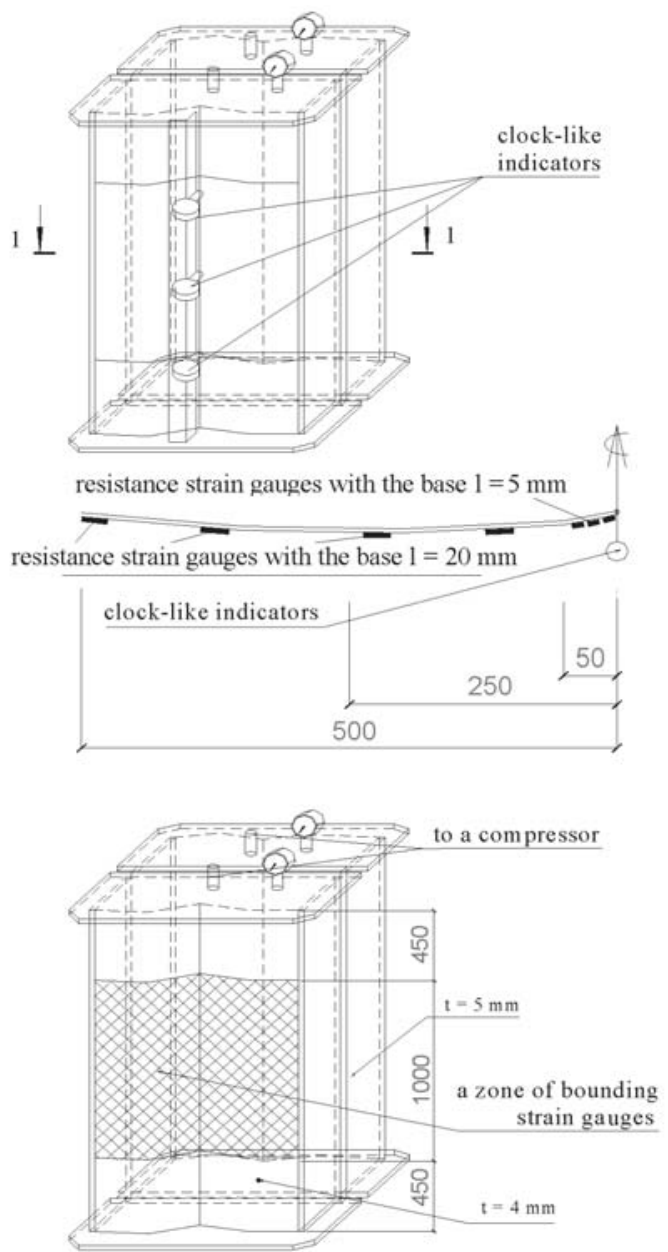

Fig 9. Model of field joint zone of a VCT wall with an angular geometrical imperfection

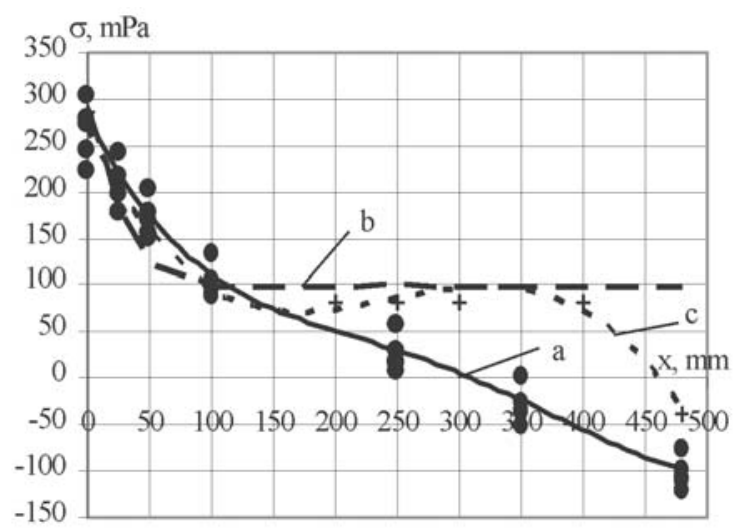

Fig 10. Epure of hoop stresses: a - an experimental epure of hoop stresses; $b-a$ theoretical epure of stress in an aroundweld zone of a VCT model; c - using programme system SCAD 7.29

In the testing process the shell relative deformations were measured with wire strain gauges, the latter having the nominal length of $20 \mathrm{~mm}$ and begin placed at $50 \mathrm{~mm}$ from one another. The width of the zone glued with strain gauges is $1000 \mathrm{~mm}(500 \mathrm{~mm}$ to the right of the joint and $500 \mathrm{~mm}$ to the left).

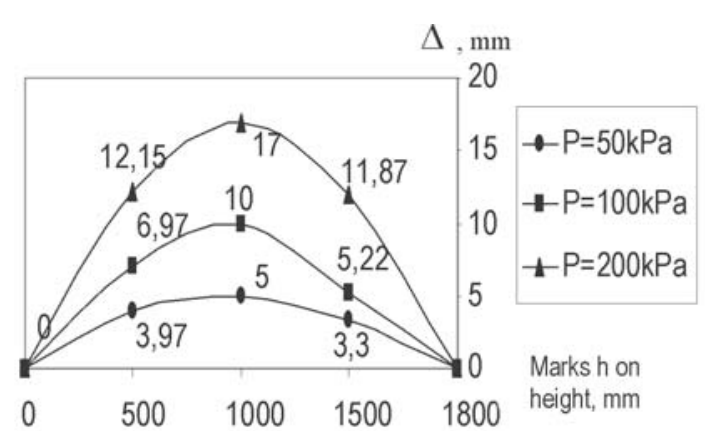

Fig 11. Horizontal movings of a joint at various sizes of internal pressure

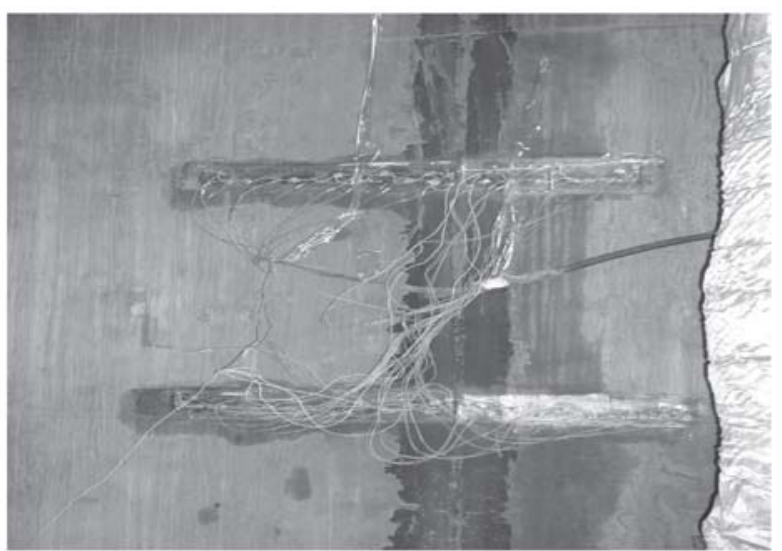

Fig 12. The field joint zone glued to strain gauges

Strain gauges were placed on the sheets of the II zone, the first axis being at the height of $1650 \mathrm{~mm}$ - the second at the $2200 \mathrm{~mm}$ height from a chime joint (Fig 13).

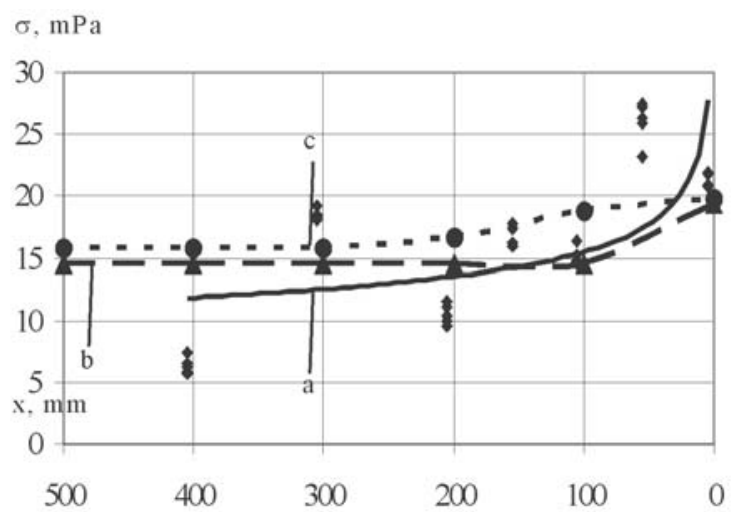

Fig 13. Projection of the hoop stresses inside VCT wall: $\mathrm{a}$ - experimental values; $\mathrm{b}$ - theoretical values; $\mathrm{c}$ - using programme system SCAD 7.29

The tests were carried out in August, 2003 in the territory of Zuyevskaya TPS fuel oil handling system at the air temperature of $30 \ldots 35^{\circ} \mathrm{C}$. The dependences obtained during the experimental study have been processed by the least-squares technique and mathematical statistics technique using PC. Hoop stresses values are given in Fig 13: 
a) values obtained during the experiment;

b) values obtained by calculating using developed technique;

c) values obtained by numerical research.

Traditional calculating scheme of the tank in the form of assumed strip does not allow to record meridian stresses, but these values can be obtained by experimental and numerical research.

In the process of the experiment there has been determined that hoop stresses within a joint are $22 \ldots .25 \mathrm{mPa}$ with principal hoop stresses $12 \ldots 15 \mathrm{mPa}$. Using programme system SCAD and the developed technique for determining SSS in weld affected zone gives the value of local hoop stresses $19,7 \mathrm{mPa}$ at hoop stresses $14,5 \mathrm{mPa}$ (Fig 13).

\section{Numerical research of welding zone}

Numerical research has been carried out with programme complex SCAD ${ }^{\circledR} 7.29$, using finite element method. The tank was supposed to project level of the liquid. In this case the determined value of geometrical imperfection as of the arrow of sinking $25 \mathrm{~mm}$ was simulated. The obtained results are shown in Fig 14. The results of similar studies are obtained in paper [20]. Thus, it is necessary to note that probabilistic methods exist in the form of the account of random character of geometrical imperfections as an additional stiffness matrix at a stage of formation of finite element stiffness matrixes [21].

Numerical researches of SSS by the finite element method proved theoretical calculation and have good correlation with experimental results.

The additional numerical researches were carried out for tanks with the volume of $10000 \ldots 30000 \mathrm{~m}^{3}$. It permitted to determine the actual relation of the hoop and meridian stresses inside the recommendations for the express-control of the field joints of tank in use (Fig 15).

While calculating tanks, the yield point value $\sigma_{\mathrm{y}}$ taken from the certificate or obtained from the results of nondestructive testing or sampling, is used instead of value $R_{y}$.

The following conditions should be satisfied:

$$
\begin{gathered}
k \cdot \sigma_{2} \leq \sigma_{y}, \\
f \leq[f],
\end{gathered}
$$

where $k$ - bearing capacity margin factor conditioned by the relation $\sigma_{M} / \sigma_{H}$ (according to Fig 16).

$[f]$ - sag legitimate value taken according to the data of Table 2 .

The ultimate goal of carried out research to increase the reliability of designed and maintained structures of vertical cylindrical tanks. This increase may be achieved into ways:

a) by perfection of methods of calculation and designing, as it is executed in the given work;
Table 2. Maximum allowable values of field joints sag

\begin{tabular}{c|c|c|c}
\hline \multirow{2}{*}{ Ry } & $\begin{array}{c}\text { The number } \\
\text { of pouring } \\
\text { in/out cycles } \\
\text { per year }\end{array}$ & $\begin{array}{c}\text { Steel } \\
\text { thickness, } \\
\mathrm{mm}\end{array}$ & $\begin{array}{c}\text { Maximum } \\
\text { allowable } \\
\text { value of joint } \\
\text { sag }\end{array}$ \\
\hline \multirow{2}{*}{$\begin{array}{c}\text { Less than } \\
300 \mathrm{mPa}\end{array}$} & Less than 10 & $5 \ldots 16$ & $3 \mathrm{t}$ \\
\cline { 3 - 4 } & $10 \ldots 20$ & $5 \ldots 10$ & $2,5 \mathrm{t}$ \\
\cline { 3 - 4 } & $11 \ldots 16$ & $2 \mathrm{t}$ \\
\hline \multirow{2}{*}{$\begin{array}{c}\text { More than } \\
300 \mathrm{mPa}\end{array}$} & Less than 10 & $5 \ldots 16$ & $2,75 \mathrm{t}$ \\
\cline { 2 - 4 } & $10 \ldots 20$ & $5 \ldots 10$ & $2,5 \mathrm{t}$ \\
\cline { 3 - 4 } & & $11 \ldots 16$ & $1,75 \mathrm{t}$ \\
\hline
\end{tabular}

b) by maintenance of performance of the requirements showed to maintained structures of tanks, as it is made in domestic norms and scientific works $[2,16]$, in works of the Russian experts [22], in European norms [23].

6. An example of calculation is given for a tank of the volume $30000 \mathrm{~m}^{3}$ at the Uglegorskaya HES to store fuel oil

By formulas (1)-(5) we'll have the following result:

a) $\varphi=\frac{\sigma_{h}}{R_{y}}=\frac{89,31}{315}=0,284$;

b) $1+2 \varphi<B<1,5(1+\varphi) ; B=1,6 ;\left(\xi=\frac{3-B}{2}=0,7\right)$;

$\mathrm{b}=1$;

c) $S=\frac{I}{I_{0}}=1+\frac{3}{2}(1-1) \cdot 0,7\left(1-0,1988^{2}-\frac{0,7^{2}}{3}\right)=1$,

d)

$$
L=\left(1-\varphi^{2}\right)(3-2 \xi) \sigma_{y}=\left(1-0,284^{2}\right)(3-2 \cdot 0,7) \sigma_{y}=1,47 \sigma_{y} .
$$

According to this technique, the stress in a weld is:

e) $\sigma=1,47 \sigma_{y}$.

If a coefficient of variation $\mathrm{V}=5 \%(0,05)$, we shall have the following result:

f) $J=(3-2 \xi) \varphi^{2} \bar{\sigma}_{y}=0,129 \bar{\sigma}_{y}$;

$$
K=\frac{\varphi \xi}{\xi+\beta(1-\xi)}=\frac{0,284 \cdot 0,7}{0,7+1(1-0,7)}=0,1988
$$

g) $H=\frac{3 K^{2}(1-\beta) \xi}{S}=\frac{3 \cdot 0,1988^{2}(1-1) \cdot 0,7}{1}=0$ 


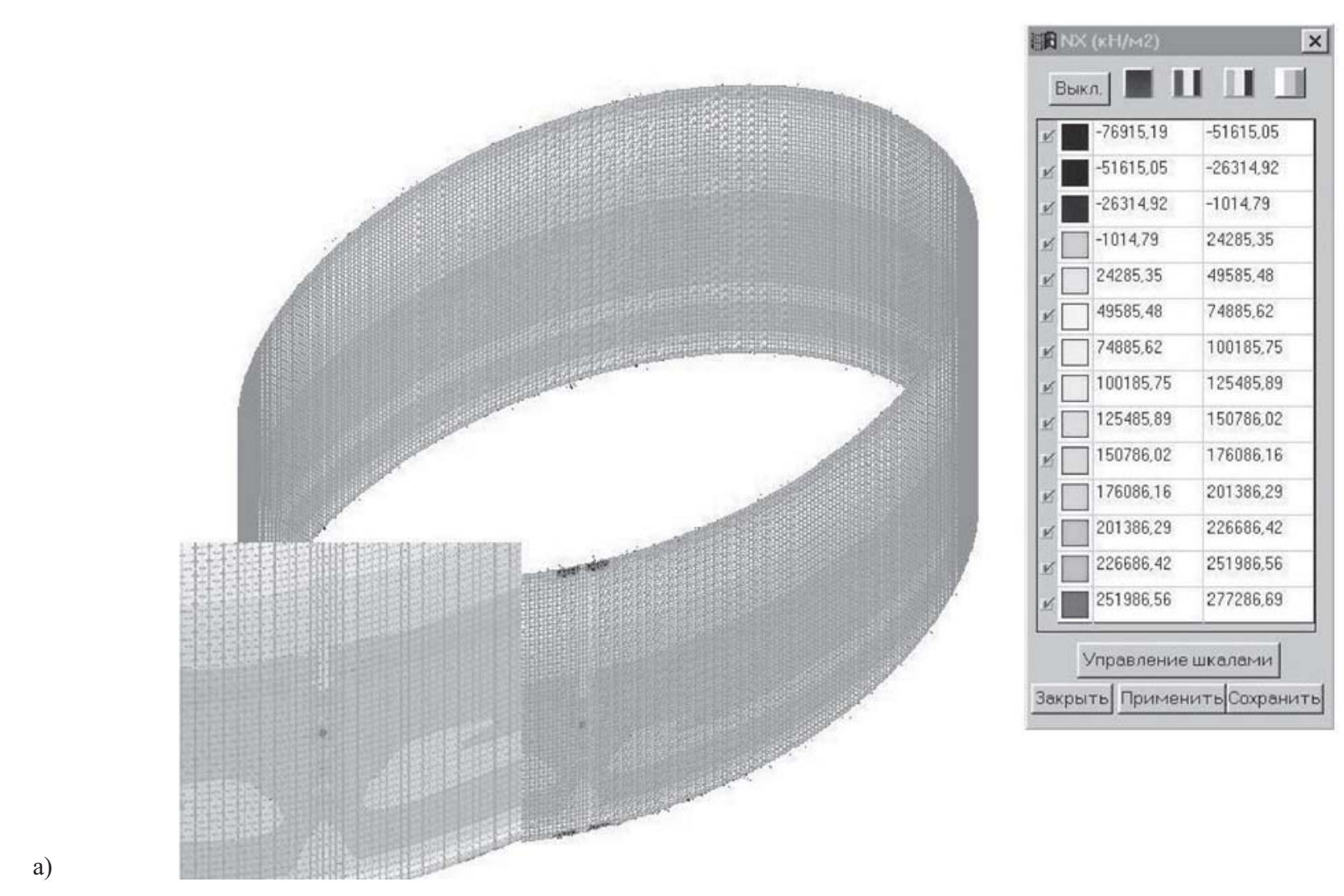

a)

b)

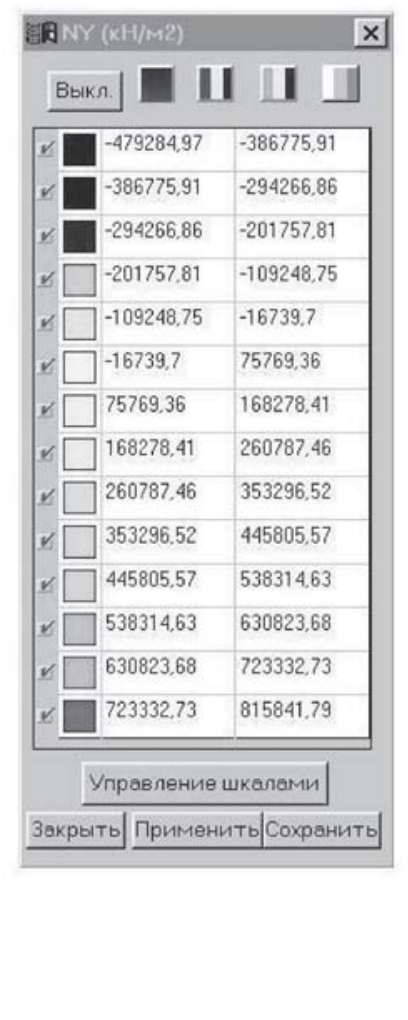

Fig 14. Results of calculation of SSS in the wall of a tank: a) hoop stresses); b) membrane stresses 


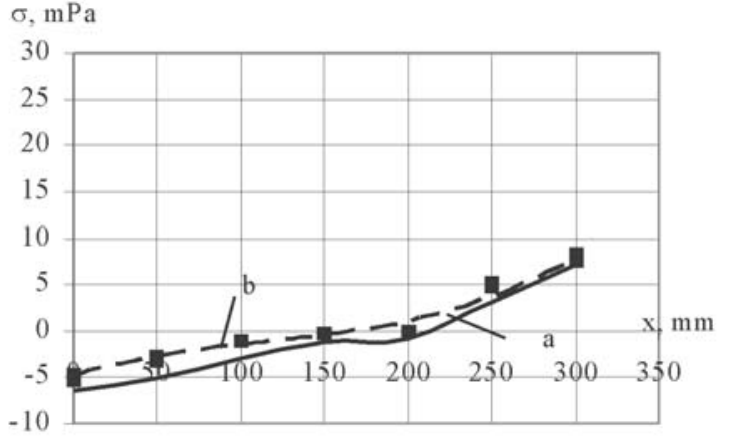

Fig 15. Projection of the meridian stresses inside VCT wall: $\mathrm{a}$ - experimental values; $\mathrm{b}$ - using program system SCAD 7.29

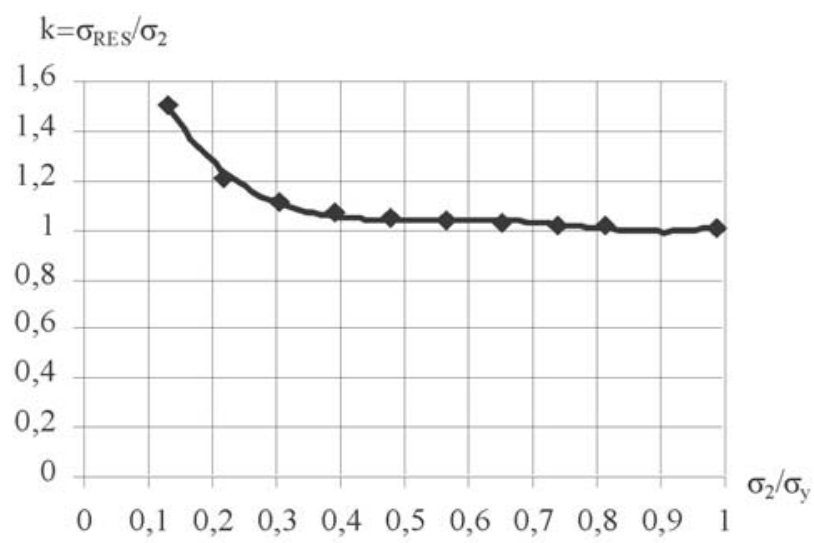

Fig 16. Dependence diagram of bearing capacity margin coefficient on hoop stresses value

$$
\begin{aligned}
& \sigma=\beta\left\{\begin{array}{l}
\frac{L}{S}+V^{2} \frac{L(1-2 H)+J}{S}+ \\
+\frac{V^{4}}{2}[L(1+4 H(H-1)-2 H(J+L)]
\end{array}\right\}= \\
& 1\left\{\begin{array}{l}
\frac{1,47}{1} \bar{\sigma}_{y}+0,0025 \cdot \frac{1,47(1-2 \cdot 0) \bar{\sigma}_{y}+0,129 \bar{\sigma}_{y}}{1}+ \\
0,5 \cdot 3,125 \cdot 10^{-6}\left[1,47 \bar{\sigma}_{y} \cdot(1+4 \times\right.
\end{array}\right. \\
& \left.\left.\quad \times 0(0-1)-2 \cdot 0\left(0,129 \bar{\sigma}_{y}+1,47 \bar{\sigma}_{y}\right)\right]\right\} \approx 1,47 \bar{\sigma}_{y} .
\end{aligned}
$$

Then by formula (7) we have:

h) $\gamma_{c}=\frac{\sigma_{y}}{\sigma}=\frac{\bar{\sigma}_{y}}{1,47 \bar{\sigma}_{y}}=0,68 \approx 0,7$.

\section{Conclusions}

Theoretical and experimental studies lead to the following conclusions:

1. A suggested analytical technique of elastic-plastic calculation of vertical field joints with angular geometrical imperfections allows to obtain more a accurate solution in comparison with those existing.

2 . When testing the model and existing vertical cylindrical tank, let us experimentally find a value of stresses in an aroundweld zone. A comparison between experimental and theoretical studies has shown that a gap between them does not exceed $15-20 \%$.

3. A developed probabilistic interpretation of design procedure serves the basis of normalisation of an operation ratio of VCR joints produced by making strip coils, the latter allows to use their values both when designing new tanks and adjusting a stress-strained state of structures under operation.

4. For the tanks in use the recommendations for the express-control are suggested.

\section{References}

1. Galkanov, V. A.; Beljaev, B. F.; Gurov, A. I.; Kulahmetjev, R. R. Influence of design-technological imperfections on serviceability of petroleum tank metal structures. Industrial and civil engineering (Промышленное и гражданское строительство), Vol 7, 1996, p. 26-27 (in Russian).

2. Popovskij, B. V.; Barvinko, J. P.; Biletskij, S. M.; Golin'ko, V. M. An estimation of influence of geometrical form deviations on serviceability of metal tanks (Будівництво України), Vol 3, 1996, p. 33-36 (in Russian).

3. Zjulko, Ye.; Supernak, E. Specificity of welded connections in cylindrical tanks of large capacity. In: The colloquium, Sept, 3-5. Scadovsk - Krivoi Rog. Perfecting of calculation, designing, construction and repair methods of steel tanks. Kiev: SC UkrNIIprojectstalconstruktsyja by V. N. Shimanovsky, 2003, p. 14-15 (in Russian).

4. Rosenshtein, I. M. Failures and reliability of steel tanks. Moscow: Nedra, 1995. 253 p. (in Russian).

5. Sirokko, T. About damages to capacities - storehouses of petroleum. Azdreku Gidzutsu, Vol 3-18, 1980, p. 150-163. Translation CIC UkrSSR, Dnepropetrovsk dep. - NA-632, $18 \mathrm{p}$.

6. Arboch, J. Study of shell buckling: theory and applications. In: Buckling and crippling of structures: theory and applications / Under edition. J. Hant. Moscow: Nauka, 1991, p. 42-68.

7. Kamyab, H. Displacements and stresses in oil storage tanks caused by differential settlement. London, 1987. 256 p.

8. Recommendations for fatigue durability calculation of vertical cylindrical tanks. Moscow: TSNIIPSK, 1987. 31 p. (in Russian).

9. The guidelines of calculation of fatigue life of vertical cylindrical tanks. Moscow. Central Research and Design Institute of Steel Structures named after N. P. Mel'nikov, 1987. 31 p. (in Russian).

10. Sobolev, Yu.V.; Koloskov, A. D. Stress-strain state of vertical cylindrical tank assembly joint. Structural mechanics and calculation of facilities, No 4, 1986, p. 24-27 (in Russian).

11. Kartashov, V. A.; Koloskov, A. D. etc. Influencing geometrical imperfections and features of exploitation on activity of some sorts sheet structures. Research work report, No SR 01840041600. Saransk, 1986. 86 p. (in Russian).

12. Perfecting welded metallical structures. / Under M. M. Jerbin reduction; Ukraine AS E. O. Paton Institute of Electric Welding. Kiev: Naukova dumka, 1992. 276 p. (in Russian). 
13. Grudev, I. D.; Lysenko, A. E. Calculation of a wall of the cylindrical tank in account of initial imperfections of the form. Rostov on the Don: SevkavNIPIagroprom, 1990. 96 p. (in Russian).

14. Yegorov, Ye. A. Research and methods of a settlement estimation of durability, stability and a residual resource of the steel tanks which take place in operation. Dnepropetrovsk: Navchalna kniga, 2002. 95 p. (in Russian).

15. Pircher, M.; Bridge, R. The influence of circumferential weld-induced imperfections on the buckling of silos and tanks. Journal of Constructional Steel Research, Vol 57, Issue 5, 2001, p. 569-580.

16. The departmental building norms of Ukraine. Vertical cylindrical tanks for storage of oil and petroleum with pressure of saturated steam are not higher than $93,3 \mathrm{kPa}$. (Резервуари вертикальні циліндричні для зберігання нафти та нафтопродуктів 3 тиском насичених парів не вище 93,3 кПа). VBN V2.2-58.2-94. Kiev, 1994 (in Ukrainian).

17. Shimanovsky, A.V.; Gordeyev, V. N.; Manshin, N. N. Experience in design and construction of various capacity and multipurpose steel tanks. In: Abstracts of the Colloquium "The Steel Tanks: Constructions, Welding, Diagnostics, Repair, Service Life". International Association for Shell and Spatial Structures (IASS). Varna, 2004, p. 7-9.

18. Turkin, V. S. Bending and calibration of tubes with elastic-plastic deforming of metal. Calculation of designs work- ing in elastic-plastic stage: The accumulator cell of the articles. Central Research and Design Institute of Building Constructions, Issue 7. Moscow, 1961 (in Russian).

19. Augusty, G.; Baratta, A.; Casciati, F. Probabilistic methods in structural engineering. London, New York: Chapman and Hail, 1984. 584 p.

20. Godoy, L. A.; Sosa, E. M. Localized support settlements of thin-walled storage tanks. Thin-walled structures, Vol 41, Issue 10, 2003, p. 941-955.

21. Mushchanov, V. F. The account of influence of geometrical imperfections in calculations thin-sheet metal structures. In: Reliability and reconstruction of buildings and constructions (Сб. научн. тр. „Надежность и реконструкция зданий и сооружений“). Makeyevka: DonICI, 1994, p. 32-42 (in Russian).

22. Beljaev, B. F.; Galkanov, V. A. Prolongation of service life and increase of working technological volume of steel tanks at their reconstruction. Industrial and civil engineering (Промышленное и гражданское строительство), Vol 5, 1998, p. 33-36 (in Russian).

23. De Jong, J. An Introduction to the EEMUA publications No 159 - Users guide to the inspections, maintenance and repair of above-ground vertical cylindrical steel storage tanks. In: Intern. conference on design, inspection, maintenance and operation of cylindrical steel tanks and pipelines. Prague, Czech Republic. Oct 8 to 10, 2003, p. $77-85$.

\section{VERTIKALUS CILINDRINIS REZERVUARAS SU KAMPINIAIS GEOMETRINIAIS TRŪKUMAIS}

\section{J. Gorochov, V. Muščanov, A. Kulik, A. Tsyplukhin}

Santrauka

Pateikti šalia siūlès esančios zonos įtempių ir deformacijų būvio eksperimentinių tyrimų rezultatai. Tyrimai atlikti dideliu matmenų vertikalaus cilindrinio rezervuaro montažinès siūlès zonos su geometriniais trūkumais modeliui. Nustatytos priklausomybės tarp svarbiausių įtempių, kurie atsiranda idealios formos rezervuaro sienoje, ir vietiniu įtempių, kurie atsiranda siūlès zonoje. Eksperimentais įrodyta, kad įtempiams žiedine linkme pasiekus $100 \mathrm{MPa}$, vietiniai įtempiai netoli siūlès zonos pasiekia 280-300 MPa. Šios ịtempių reikšmès patenkinamai sutapo su teorinių tyrimų rezultatais.

Raktažodžiai: vertikalus cilindrinis rezervuaras, itempių ir deformacijų būvis, stačioji virintinè siūlè, geometriniai trūkumai, ¡̨linkis.

GOROCHOV Yevgeny Vasylievich - Rector, chief of Metal structure Dept of the Donbass National Academy of Civil Engineering and Architecture, Makeyevka, Ukraine. He is member of Academy of Higher School of Ukraine, member of Russian Academy of Architecture and Building Sciences, President of the Ukrainian Association on Metal Structures, MICE (Fellow), DSc, P rof, Winner of the State Premium of Ukraine in the sphere of science and engineering. The real behaviour and exploitation reliability of building metal structures is the sphere of his scientific activity.

MUSCHANOV Vladimir Filippovich - Vice-Rector for scientific activity, chief of Theoretical and Applied mechanics Dept of the Donbass National Academy of Civil Engineering and Architecture, Makeyevka, Ukraine. DSc, Prof, member of Academy of Building of Ukraine, MICE (member). The elaboration computational methods and designing thin-walled spatial structures (membrane structures of large-span roofs and vertical cylindrical tanks, first of all) is the sphere of his scientific activity.

KULIK Alexander Alexandrovich, $\mathrm{PhD}$, practising engineer. Sphere of his scientific activities - study of real behaviour of vertical cylindrical tank structures.

TSYPLUKHIN Alexander Gennadievich - Master of Civil Engineering, post-graduate student of the Donbass National Academy of Civil Engineering and Architecture, Makeyevka, Ukraine. Sphere of his scientific activity - the optimal designing of membrane roofs of buildings and engineering structures. 